\title{
NOTES ON A SPRUCE BUDWORM INFESTATION IN BRITISH COLUMBIA ${ }^{1}$
}

\author{
BY G. T. SILVER ${ }^{2}$
}

\begin{abstract}
An outbreak of the one-year cycle spruce budworm, Choristoneura fumiferana (Clem.), on Douglas fir, Pseudotsuga menziesii (Mirb.) Franco, which lasted six years before collapsing, is described. Population trends and seasonal development, effect of defoliation on the host trees and parasites of the insect are discussed.
\end{abstract}

\section{INTRODUCTON}

The spruce budworm in British Columbia is thought to be the same species that has caused such severe damage to balsam and spruce stands in eastern Canada and in the United States. In British Columbia the species may have a one-year cycle or a two-year cycle depending on locality and altitude. Although there are a number of reports on the spruce budworm in British Columbia, no comprehensive history of any infestation has been published.

This paper describes a recent outbreak of the one-year cycle spruce budworm on Douglas fir, in the Lillooet and Fraser River regions. The relative inaccessibility of the Lillooet River area seriously handicapped the work but annual records were obtained on population trends, defoliation, and tree recovery. As it may be some time before there is another opportunity for a similar study, the results of these records and observations are worthy of a historical review.

That portion of the spruce budworm infestation in the region along the Lillooet River north of Tenas Lake and eastward along the Anderson and Seton lakes, according to climatic regions after Köppen, is classified as humid continental (1). The winters are cold with abundant snow, and the summers are cool and dry. This is referred to as Region 1 in this paper. The Lillooet River Valley south of Tenas Lake, referred to as Region 2, is also classified as humid continental, but differs from Region 1 by having moist summers. The valleys of both regions are flanked by mountain ranges which are capped by glaciers.

The forest composition varies. Western red cedar, Thuja plicata Donn, predominates along the broad flats of the river bottom above Lillooet Lake. Where flooding has occurred black cottonwood, Populus trichocarpa Torr. and Gray, is present. Douglas fir predominates on the better drained sites and on the slopes. Lodgepole pine, Pinus contorta Dougl. var. latifolia Engelm., replaces Douglas fir south of Gowan Creek and, in association with alpine fir, Abies lasiocarpa (Hook) Nutt., becomes the major species at elevations above 5,000 feet.

\footnotetext{
${ }^{1}$ Contribution No. 684, Forest Biology Division, Research Branch, Department of Agriculture, Ottawa, Canada. Cost of publication shared by Forest Biology Division and the C.L.F.

- Forest Biology Laboratory, Victoria, B.C. Biographical note in For. Chron. 34: 299.
} 


\section{Methods and Scope of STUdy}

As accessibility was a major problem the main objectives of the study were defined as an annual estimate of the population trend, and an estimate of the damage to the host trees.

The extent and intensity of the infestation were obtained by both aerial and ground surveys. Seventeen study plots were established in 1954 at seven areas along the Lillooet River and Lake; areas 1-3 were in Region 1 and areas 4-7 were in Region 2 (Figure 1). Annual records from these plots were supplemented by additional sampling points which were usually sampled annually once established. Ten Douglas-fir trees were tagged in each plot and the d.b.h. measured. Ocular estimates were made of the percentage of current and total defoliation as well as bud condition for each tree. One untagged

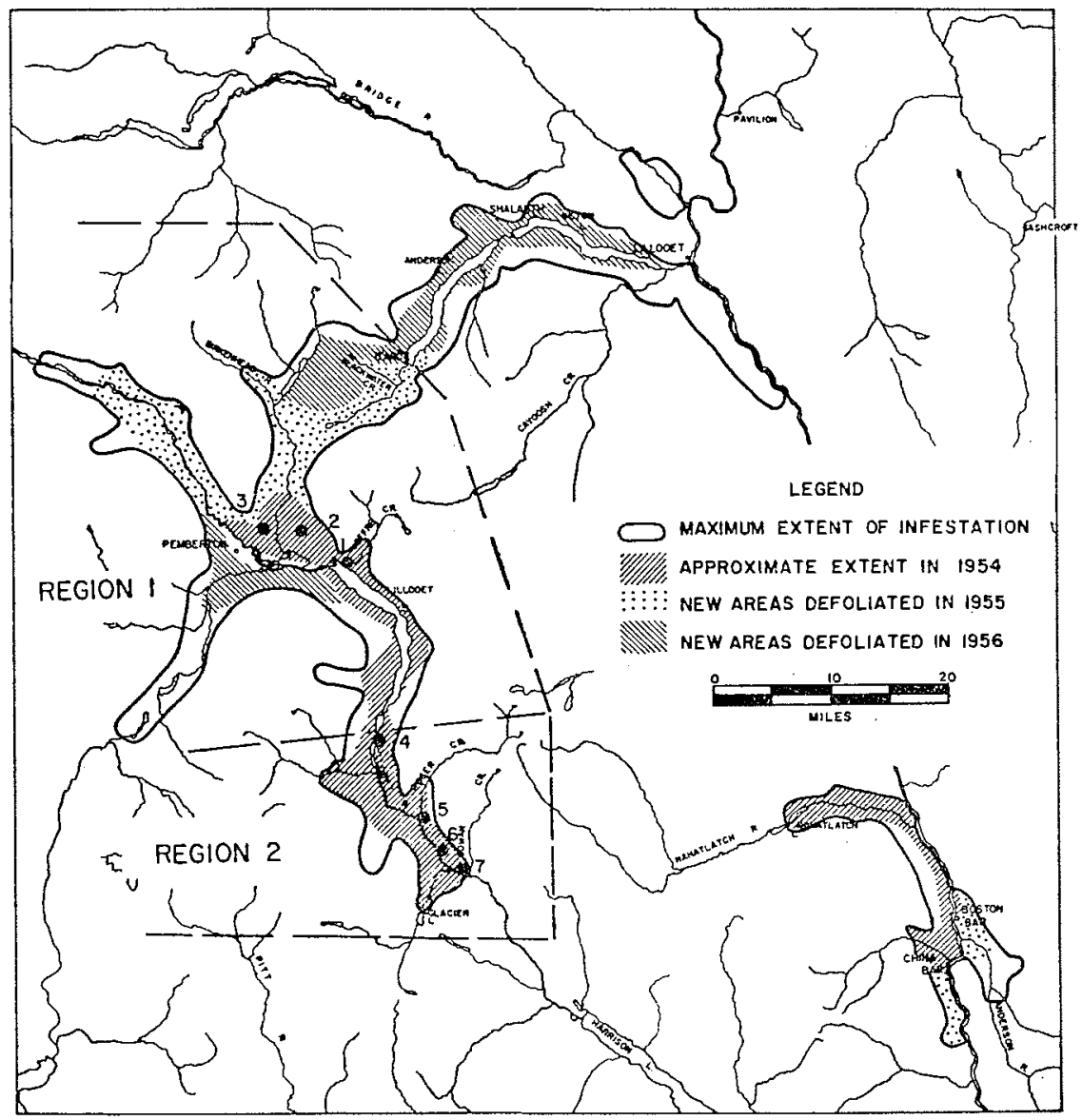

FIGURE 1. Map showing maximum extent of spruce budworm infestation, new areas of defoliation in 1954, 1955, and 1956, and study areas and regions. 
tree was cut in each plot, two branches selected from the center third of the crown, the foliage area measured, and examined for egg masses and pupal cases. Population level was expressed as the number of egg masses per 100 square feet of foliage surface, hereafter referred to simply as egg masses. Fifty buds were selected at random from each branch and classified as killed, completely or partially defoliated.

Development studies were conducted in 1955 at Owl Creek, east of Pemberton, on three plots at elevations of 1,260, 2,240, and 3,060 feet. ${ }^{3}$ Mass collections of larvae were reared at the Langford Insectary, Victoria, for parasites.

\section{Seasonal Development}

\section{RESULTS}

The one-year cycle spruce budworm in British Columbia has six larval instars. Instars were defined using the width of the head capsules as the primary feature. Larval instars compared closely in head width with those of Ontario (3), with the fifth and sixth instars in British Columbia being slightly larger for both sexes.

In 1955 the development of the spruce budworm varied with elevation. Larvae had already emerged at the 1,240 foot level on May 29; estimates placed the beginning of emergence at least one week earlier. Emergence reached its peak on June 1 and was completed by June 7 . This was considerably earlier than at the 3,060 foot level where emergence began on June 4, reached a peak on June 9, and was completed on June 14.

Larval emergence preceded bud swelling at all elevations in 1955 and larvae mined the needles. The first buds opened on June 1 at the lower level, and no new needle mines were observed after June 4 . The first buds opened at the 3,060 foot level on June 13, 9 days after the first larvae emerged. Larval emergence and bud opening at the 2,240 foot level was approximately midway between the upper and lower levels.

The rate of development for the lower level is shown in Table 1 , and for the upper level in Table 2. The data for the 2,240 foot level are not shown, but fell about midway between the other two plots. The tables indicate development was more rapid at the lower elevation. On June 4, 95 per cent of the larvae were in the third and 5 per cent in the fourth instar, while at the upper level 64 per cent of the larvae were in the second instar, and none in the fourth. On July 26, the last comparable date, the difference was even greater. At the lower level 80 per cent of the moths had emerged, and nearly all the remainder were pupae; above 3,000 feet only 6 per cent were adults, the majority were pupae, and some third-instar and fourthinstar larvae were still present. Some of the spruce budworm above 3,000 feet might be two-year-cycle and they would overwinter as fourth-instar larvae. This could account for the relatively large percentage in this stage.

The average number of days spent in instars III to VI, as determined for the lower level by individual rearings, were 4.0, 4.6, 5.7, and 12.9 respectively. The pupal stage lasted an average of 16.9 days.

${ }^{2}$ G. S. Brown. 1956. Studies on the spruce budworm in southern British Columbia. Interim Report 1955. pp. 15-45. Forest Biology Laboratory, Victoria, B.C. 
TABLE 1

Percentage Occurrence of Larval Instars and Stages of the Spruce BUdWORM AT THE 1,260 FoOT LeVel, OWL CReEK. 1955.

\begin{tabular}{|c|c|c|c|c|c|c|c|c|c|}
\hline \multirow[b]{2}{*}{ Date } & \multirow{2}{*}{\multicolumn{2}{|c|}{$\begin{array}{l}\begin{array}{l}\text { No. of } \\
\text { insects }\end{array} \\
\end{array}$}} & \multicolumn{7}{|c|}{ Larval Instars } \\
\hline & & & II & III & IV & & vi & Popa & Adult \\
\hline May & 29 & 110 & 23.6 & 76.4 & & & & & \\
\hline June & 1 & 118 & 11.9 & 83.9 & & & & & \\
\hline June & 4 & 120 & & 95.0 & 5.0 & & & & \\
\hline June & 7 & 112 & & 16.1 & 83.0 & 0.9 & & & \\
\hline June & 9 & 146 & & 1.4 & 49.3 & 49.3 & & & \\
\hline June & 13 & 211 & & & 34.6 & 65.4 & & & \\
\hline June & 21 & 160 & & & & 30.0 & 67.5 & 2.5 & \\
\hline June & 30 & 128 & & & 6.3 & 11.7 & 75.8 & 6.3 & \\
\hline July & 6 & 125 & & & & 0.9 & 27.2 & 72.0 & \\
\hline July & 12 & 115 & & & & & 1.7 & 98.3 & \\
\hline July & $20^{1}$ & 133 & & & & & 2.3 & 41.4 & 56.4 \\
\hline July & $26^{1}$ & 123 & & & & & 0.8 & 19.5 & 79.7 \\
\hline July & $31^{1}$ & 164 & & & & & 0.6 & 12.2 & 87.2 \\
\hline
\end{tabular}

TABLE 2

Percentage Occurrence of Stages of the Spruce Budworm at tHe 3,060 Foot Level, OWl Creek. 1955.

\begin{tabular}{|c|c|c|c|c|c|c|c|c|c|}
\hline \multirow[b]{2}{*}{ Date } & & \multirow{2}{*}{$\begin{array}{l}\text { No. of } \\
\text { inseets }\end{array}$} & \multicolumn{7}{|c|}{ Percentage in stage } \\
\hline & & & II & III & IV & $\mathbf{v}$ & VI & Papa & Adalt \\
\hline$\overline{\text { May }}$ & 30 & 117 & 100 & & & & & & \\
\hline June & 2 & 176 & 52.3 & 47.7 & & & & & \\
\hline June & 4 & 136 & 64.0 & 36.0 & & & & & \\
\hline June & 6 & 257 & 77.8 & 9.7 & 12.5 & & & & \\
\hline June & 9 & 208 & 25.5 & 63.0 & 7.7 & 3.8 & & & \\
\hline June & 13 & 173 & 6.9 & 71.1 & 20.8 & 0.6 & 0.6 & & \\
\hline June & 21 & 138 & & 44.9 & 51.4 & 2.2 & 1.4 & & \\
\hline Iune & 30 & 30 & & 6.7 & 70.0 & 23.3 & & & \\
\hline July & 6 & 167 & & 13.2 & 41.3 & 33.5 & 11.4 & 0.6 & \\
\hline July & 12 & 146 & & 6.8 & 34.9 & 28.8 & 17.8 & 11.6 & \\
\hline July & $20^{x}$ & 117 & & 6.0 & 17.9 & 16.2 & 19.7 & 40.2 & \\
\hline July & $26^{1}$ & 83 & & 3.6 & 19.3 & 6.0 & 10.8 & 54.2 & 6.0 \\
\hline
\end{tabular}

No field observations were made after July 12 . No adults were observed on August 10 when an egg survey was conducted and most of the egg masses were empty. The average number of eggs per mass was 44.8 with a range of 3 to 105 eggs.

\section{History of the Infestation}

There was no report of a spruce budworm infestation in the Forest Insect Survey records in 1952. The following year, 100 per cent of the current year's foliage was defoliated in an area of 250 acres in the Anderson River Valley, 
and light defoliation occurred in the Nahatlatch River Valley, and along the slopes of the Lillooet River below Lillooet Lake, in the Blackwater Creek near D'Arcy, and near Creekside.

The population level had increased to major outbreak proportions by 1954. Heavy defoliation extended from about one mile north of Gowan Creek north along both sides of Lillooet River and Lake, and north of Pemberton to McKenzie Creek and east to Spetch (Figure 1). Two small areas of defoliation were observed at the western end of Seton Lake. In the Fraser River Valley defoliation was heavy from China Bar along the west bank of the river to Keefers, and up both sides of the Nahatlatch River Valley to the end of Nahatlatch Lake. The area of the infestation for 1954 and for the succeeding years, is shown in Table 3. In 1954 the population level, based on the number of egg masses, reached a peak resulting in maximum defoliation in 1955 (Table 4).

TABLE 3

Area of Spruce Budworm Infestation By Years and Degree of Defoliation as Determined by Aerial and Ground Surveys. Lillooet River and LaKe and Fraser River Valley Regions.

\begin{tabular}{lrrrr}
\hline & & \multicolumn{2}{c}{ Defollation in square miles } & \\
\cline { 2 - 5 } Year & Light & Medium & Feavy & Total \\
\hline 1954 & 0 & 0 & 113 & 113 \\
1955 & 0 & 0 & 379 & 379 \\
1956 & 283 & 41 & 128 & 452 \\
1957 & 387 & 33 & 78 & 498 \\
1958 & 520 & 41 & 92 & 653 \\
1959 & 0 & 0 & 0 & 0 \\
\hline
\end{tabular}

TABLE 4

Number op Spruce Budworm Egg Masses Per 100 Square Feet of Foliage Surface

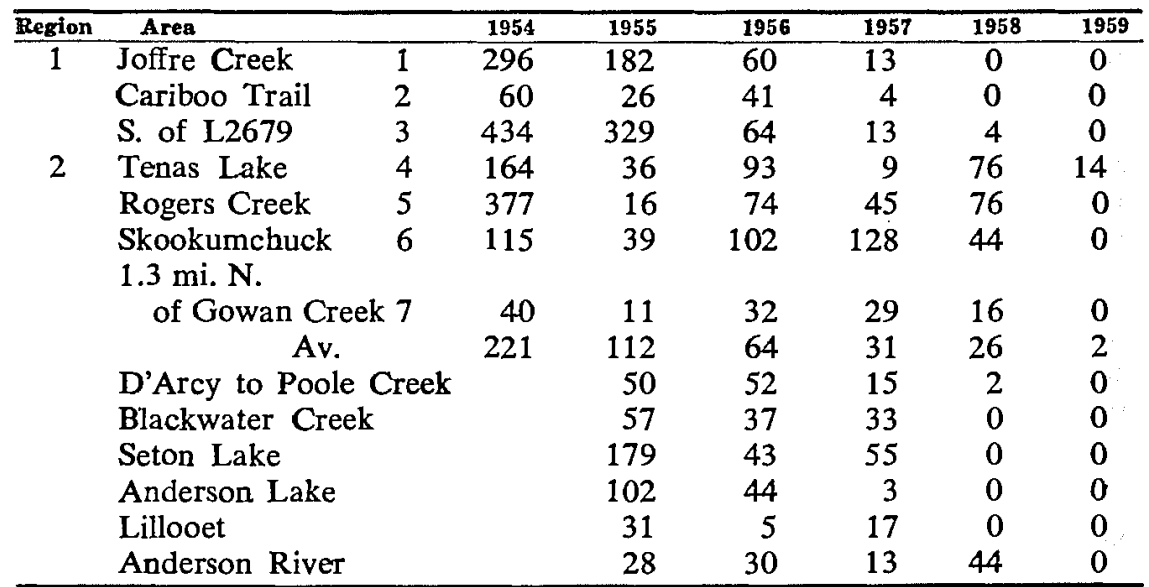


The outbreak expanded in 1955. Heavy defoliation extended north of Pemberton to the head of the valley, and eastward to the head of Anderson Lake. Defoliation was heavy in the Anderson River Valley. The number of egg masses in the fall of 1955 decreased approximately 50 per cent. Additional egg sample points were established. Although no defoliation was visible along Anderson and Seton lakes there were many eggs in several localities (Table 4). Whether the increase was due to a moth flight or a build-up of residual budworms is not known. In 1956 heavy feeding extended south-west of Pemberton as far as Tisdall, and medium defoliation occurred along both sides of Anderson and Seton lakes nearly to Lillooet, and around Birkenhead Lake. The number of egg masses decreased about 50 per cent again in 1956. The extent of the infestation changed little in 1957. Larvae were found in large numbers near Pavilion, north of Lillooet, but defoliation was light. The number of egg masses decreased again, but some areas were moderately infested. In 1958 the outbreak reached its maximum size, due mostly to feeding occurring up hillsides and small creek valleys, and to small extensions, notably westward to Alta Lake. Defoliation was light over much of the area. The number of egg masses did not decrease significantly in Regions 1 and 2 or Anderson River, but elsewhere they decreased. The outbreak collapsed in 1959 with no defoliation visible from the air.

As annual records on the seven study areas accumulated it was obvious that conditions were not uniform throughout the outbreak area. This was particularly evident when records from Regions 1 and 2 were compared.

The population level was highest in stands in Region 1 (Areas 1-3). Average defoliation and bud condition in relation to the number of egg masses for this area are shown in Figure 2. The number of egg masses decreased steadily each year from 1954. Defoliation of current year's growth dropped sharply in 1956. This was due in large part to the heavy bud kill and lack of new foliage which resulted in starvation of the 1956 larval population. In some areas all buds were killed in 1954, and although many adventitious buds were put out in 1955 new growth was very short and stunted. Budworms did not mine the small buds, and there was a decided lack of suitable needles for mining. Light defoliation in 1956 increased the number of normal buds. In 1957 a cool damp spring retarded larval development but foliage growth was excellent. The percentage of new foliage lost in 1957 was very low but total defoliation increased because the new growth was unable to compensate for old needle drop. Some defoliation occurred in 1958 although the number of egg masses in August, 1957, was less than the previous year. No defoliation occurred in 1959 , all buds were normal, and total defoliation averaged less than 23 per cent, indicating the stands were recovering.

The sequence of events in Region 2 (Areas 4-7) was noticeably different. In 1954 there were fewer egg masses below Lillooet than farther north, but defoliation increased in 1955, and bud kill was heavy for the second successive year. Heavy back feeding associated with heavy bud kill resulted in a scarcity of food in 1956, and this combined with a greatly reduced number of egg masses resulted in reduced defoliation and a noted recovery in tree condition (Figure 3). The number of egg masses increased in the fall of 1956, and 


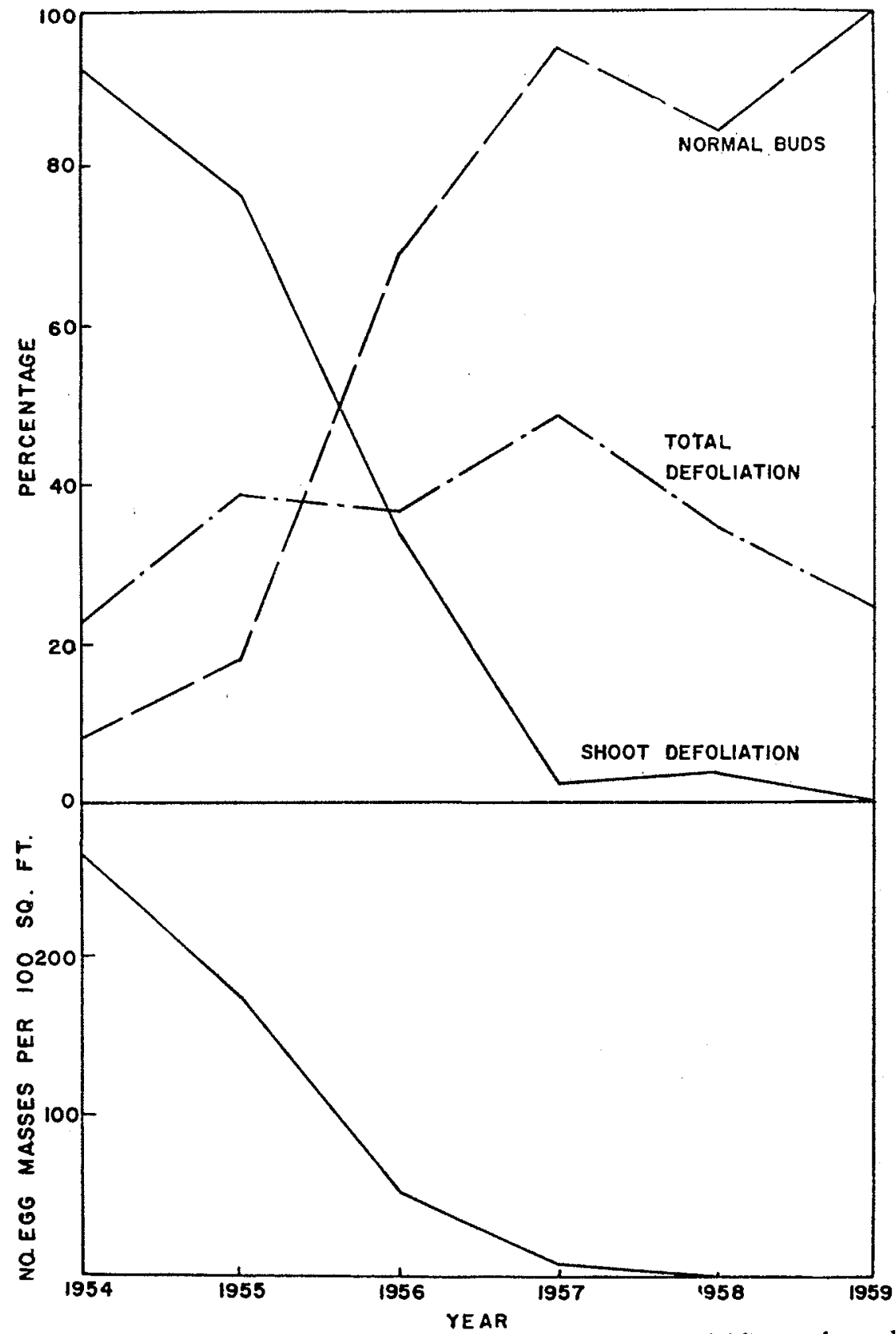

FIGURE 2. Number of spruce budworm egg masses per 100 square feet of foliage surface and associated tree condition in Region 1 north of Lillooet Lake, B.C. 
in 1957 defoliation was heavy in localized areas. Similar conditions were experienced again in 1958, and some stands, particularly at the Skookumchuck (Area 6), were heavily damaged. Total defoliation there averaged 58 per cent and some trees were 90 per cent defoliated with the top 20 to 30 feet completely stripped of all needles. Although the number of egg masses in

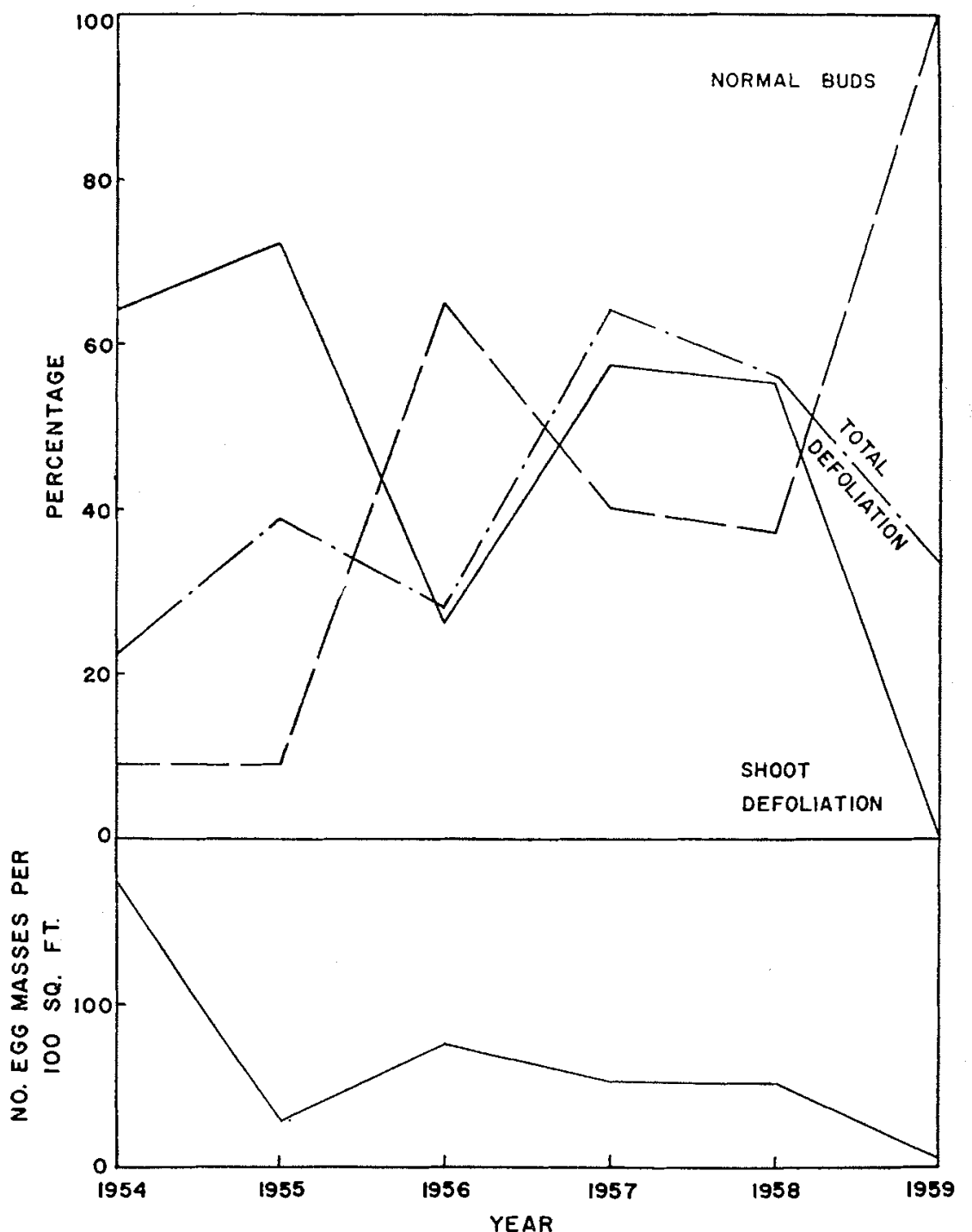

FIGURE 3. Number of spruce budworm egg masses per 100 square feet of foliage surface and associated tree condition in Region 2 along the lower Lillooet River, B.C. 
Region 2 in 1958 averaged the same as the previous year, defoliation was extremely light in 1959. Most of the tops which had been completely defoliated put out adventitious buds and showed signs of recovery.

The differences between these two regions was therefore quite marked. The population along the lower Lillooet River in Region 2, where defoliation was first observed in 1953, was never as high as it was farther north; it decreased markedly in 1956, and then increased again. The number of egg masses in the different areas fluctuated from year to year. This was in contrast to Region 1 where the population was highest but decreased slowly and steadily, and reached a low level one year earlier. The newer areas of infestation north and east of Pemberton, and along Anderson and Seton lakes followed a similar trend, building rapidly to a maximum in 1955, and then decreasing steadily to negligible proportions in 1958 (Table 4). The number of egg masses in the Anderson River Valley increased in 1958, but the population failed to develop in 1959.

\section{Relationship of Egg Counts to Defoliation}

During the field observations, damage to trees was classified as light, medium, and heavy according to the loss of new foliage, which was divided into classes of $1-25,30-60$, and 70 or more per cent respectively. The number of egg masses associated with these defoliation ratings were grouped and no correlation was found when analysed for all years; when the data were grouped by age of the outbreak, some general trends were obtained. Although the averages were reasonably consistent for the light and medium classes, the averages in the heavy class varied greatly with number of years of defoliation, and the ranges for all three classes overlapped. It was therefore considered unsafe, with the existing data, to draw up precise infestation classes based on number of egg masses. As a guide it is suggested that counts of over 150 egg masses per 100 square feet of foliage surface could result in heavy defoliation, and counts of from 50 to 145 egg masses could result in medium defoliation. There would be exceptions depending on age of the infestation and the intensity of previous defoliation.

\section{Effects of defoliation on tree growth}

Radial increment was measured from discs taken at d.b.h. from each sample tree in each area. The effect of defoliation on annual increment is shown in Figure 4. The years 1949 and 1950 were used as a base for estimating decrease in growth. The drought years of 1951 and 1952 resulted in a small average decrease in radial increment. The severe defoliation of 1954 and 1955 resulted in small decreases in radial growth, but the effect became most conspicuous in 1956. Up to this point the radial growth patterns for both regions were similar. Shoot defoliation was very light in Region 1 in 1957, and foliage growth was good after this year (Figure 2). Tree recovery is indicated by the increase in radial increment which was obvious in 1958 and continued in 1959. Defoliation in Region 2 was heavy in 1957 and 1958. Radial increment in this region continued to decrease slowly up to and including 1959.

Foliage growth should be a reliable measure of tree recovery. Preliminary work shows that under normal conditions the current year's foliage growth 


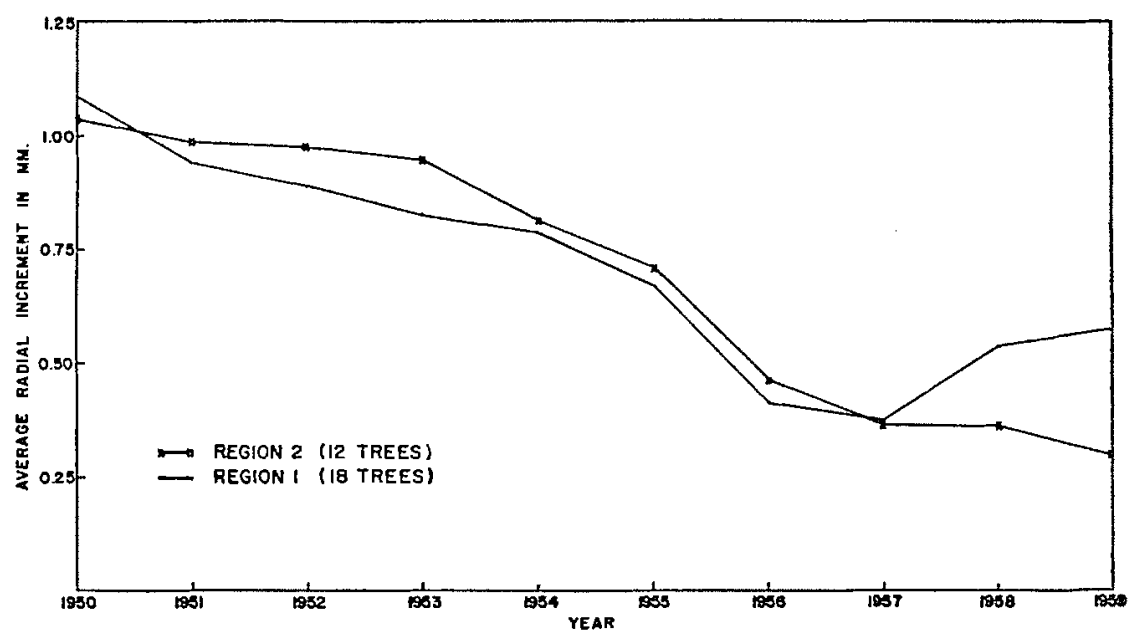

FIGURE 4. Average radial increment of Douglas-fir trees in Region 1 and Region 2 of the spruce budworm infestation, Lillooet River, B.C.

on Douglas fir ranges from 20 to 30 per cent of the total amount of foliage on a tree. When heavily defoliated stands start recovering from several years of severe damage, the current year's growth represents a major proportion of the total foliage. As the tree recovers, the percentage of total foliage contained in the current year's growth decreases until it reaches a level of from 20 to 30 per cent. At this point the tree could be considered recovered in respect to foliage complement.

During the egg survey in August, 1959, the foliage complement of nine sample trees in different areas was measured (Table 5). The samples from Region 1 indicate that the tree crowns have almost returned to normal with

TABLE 5

Percentage of Total foliage by Age on Sample Trees at Selected localities. Lillooet River. August, 1959

\begin{tabular}{|c|c|c|c|c|c|c|c|c|c|}
\hline$\overline{\text { Region }}$ & Locality & & 1959 & 1958 & 1957 & 1956 & 1955 & 1954 & 1953 \\
\hline 1 & Normal trees ${ }^{1}$ & $1 \mathrm{c}$ & 19.0 & 43.6 & 31.5 & 14.8 & 10.7 & 7.1 & 4.4 \\
\hline 1 & Joffre Creek & $1 \mathrm{c}$ & 19.0 & 43.6 & 31.5 & 5.8 & 0 & 0 & 0 \\
\hline \multirow[t]{2}{*}{1} & Cariboo Trail & $2 b$ & 22.3 & 29.3 & 27.3 & 14.8 & 5.5 & 0 & 0.9 \\
\hline & & $2 c$ & 28.3 & 27.6 & 30.0 & 13.8 & 0.4 & 0 & 0 \\
\hline \multirow[t]{2}{*}{1} & South of L2679 & $3 a$ & 35.1 & 34.9 & 24.4 & 5.4 & 0.2 & 0 & 0 \\
\hline & & $3 c$ & 37.4 & 36.8 & 23.0 & 2.7 & 0.1 & 0 & 0 \\
\hline \multirow[t]{2}{*}{2} & Tenas Lake & $4 a$ & 57.2 & 5.4 & 16.8 & 19.2 & 1.4 & 0 & 0 \\
\hline & & $4 b$ & 54.1 & 23.8 & 14.2 & 8.0 & 0.1 & 0 & 0 \\
\hline \multirow[t]{3}{*}{2} & Skookumchuck & $6 a$ & 96.7 & 0.5 & 1.0 & 1.8 & 0 & 0 & 0 \\
\hline & & $6 b$ & 40.0 & 20.2 & 21.4 & 15.2 & 3.3 & 0 & 0 \\
\hline & Normal trees ${ }^{1}$ & & 24.7 & 23.6 & 13.1 & 13.2 & 10.7 & 7.1 & 4.4 \\
\hline
\end{tabular}

Inpublished data.

G. T. Silver. Unpublished report. Forest Biology Laboratory, Victoria, B.C. 
three good years of foliage growth present. The stands appear in excellent condition, although experienced observers can detect such signs of recent damage as dead branch tips, and gnarled and bushy branches resulting from adventitious growth. Foliage recovery in these plots was very conspicuous in 1957, and increased radial growth was observed in 1958 (Figure 4). As radial increment in 1959 was still only slightly more than 50 per cent of the 1950 average, it appears that recovery to normal radial growth lags behind the recovery of a normal foliage complement.

Foliage analysis of trees in Region 2 reflects the heavier defoliation in 1957 and 1958. With the exception of plot 6b most of the foliage on these trees was 1959 growth. These stands will require two or more years to acquire a normal complement of foliage. Radial growth should increase in 1960 .

\section{Parasites}

Information on parasites was of a general nature only. All egg masses were examined and classified as to whether or not they contained parasites. Larval rearings were difficult because of the inaccessibility of the region.

Trichogramma minutum Ash. was the major egg parasite in 1955, the only year in which specimens were obtained. As shown below the percentage of parasitism decreased as the number of egg masses decreased.

\begin{tabular}{|c|c|c|c|c|c|c|}
\hline & 1954 & 1955 & 1956 & 1957 & 1958 & 1959 \\
\hline Number of egg masses per & & & & & & \\
\hline 100 sq. ft. of foliage & 221 & 112 & 64 & 31 & 26 & 2 \\
\hline $\begin{array}{l}\text { Percentage of egg masses } \\
\text { containing parasitized eggs }\end{array}$ & 28.8 & 27.6 & 12.9 & 7.8 & 5.9 & 0 \\
\hline
\end{tabular}

Because of the relatively small number of larvae collected, and the different larval stages collected, complete information is not available on larval parasite species. Twelve species were recovered. The first five given below are in order of their relative abundance, the others being represented by only one or two specimens: Glypta fumiferanae (Vier.), Phytodietus fumiferanae Rohw., Apanteles fumiferanae Vier., Lypha fumipennis Brooks, Winthemia fumiferanae Toth., Phorocera tortricis (Coq.), Madremyia saundersii (Will.), Itoplectis obesus Cush., Lypha setifacies (West.), Phryxe pecosensis (Tnsd.) Horogenes conodor (Vier.), and Ascogaster sp. The only hyperparasite was Mesochorus diversicolor Viereck, which was reared from one host, Apanteles fumiferanae.

As shown below pupal parasitism was lowest in 1954, reached its peak in 1955, and remained at a relatively high level for the next three years.

\begin{tabular}{lcccccc}
\hline & 1954 & 1955 & 1956 & 1957 & 1958 & 1959 \\
\hline Number of pupae collected & & & & & & \\
in the field & 665 & 206 & 117 & 86 & 32 & 0 \\
Percentage parasitized & 28.3 & 62.1 & 47.9 & 47.7 & 40.6 & - \\
\hline
\end{tabular}

In addition to examination of empty pupal cases, field collected pupae were reared. The parasite species obtained from 1955 to 1958 , in order 
of abundance were: Apechthis ontario Cress., Winthemia fumiferanae Toth., Itoplectis obesus Cush., Agria affinis (Fall.), Madremyia saundersii (Will.) and Phorocera tortricis (Coq.).

Wilkes et al. (6) listed 45 species of parasites reared from spruce budworm collected near Lillooet, British Columbia. The Forest Insect Survey files at Victoria contain records of 35 species from coastal British Columbia. In the present study only 14 species were reared, of which one, Lypha fumipennis, is a new record for British Columbia. This species does not appear in the literature known to the author, and may possibly be a new record for spruce budworm. It so, this would bring the number of spruce budworm parasites to 93, one more than previously reported (4).

\section{Predators}

A small ant, Camponotus vicinus Mayr, was present in large numbers on the ground and on the foliage in 1955. Many were observed to attack and kill fourth- and fifth-instar larvae. In 40 to 45 minutes these ants removed 40 per cent of 241 larvae placed on a beating sheet. Although this is no measure of larvae killed on the trees it does indicate that ants were active and undoubtedly killed a considerable number of the budworm larvae.

\section{Discussion and Conclusions}

The spruce budworm infestation lasted six years. With the exception of smaller areas around Boston Bar in the Fraser River Valley, the infestation was contained in the Douglas-fir stands in the humid continental region. The outbreak started in the lower Lillooet River and spread northward and eastward, being confined by mountains to the relatively narrow valleys below 3,000 feet.

Although no weather records are available the outbreak was preceded by two years of drought which was common to the lower coastal mainland of British Columbia. The lack of moisture was reflected in a decrease in radial growth. These conditions were among those associated with the development of spruce budworm outbreaks in eastern Canada (5).

The population did not act as a unit; in the lower Lillooet River Valley (Region 2) where the main outbreak started, the population level fluctuated considerably before finally collapsing. In Region 1 the population level rose to a peak in 1954, and declined steadily until it had essentially disappeared in 1958. The portion of the outbreak along Anderson and Seton lakes that was last to appear, also subsided in 1958 . The main reason for the collapse of the outbreak is unknown. It is believed that a severe shortage of suitable food along the Lillooet River resulted in heavy larval mortality, but tree recovery was good and by 1957 and 1958 there was no shortage of food. The population continued to decrease along the upper Lillooet River, but below Lillooet Lake the population which decreased in 1955 increased in 1956 and remained at a medium to high level until it disappeared in late 1958 or early 1959. Topographic effects which played a large part in confining the spread of the outbreak, could be one reason for the difference in behaviour. The Pemberton and the Anderson and Seton lakes region (Region 1) lies roughly in an East-West direction, and is exposed to any 
adverse weather which moves into it from Howe Sound and through the pass, while Region 2 which runs roughly north and south, is protected from such weather by mountain barriers.

Parasitism was not studied in detail, but one species, Lypha fumipennis is not only a new record for British Columbia but is believed to be a new record for the spruce budworm.

Of great significance was the ability of the Douglas-fir trees to sustain severe defoliation and remain alive. Numerous trees had all their buds killed, lost over 90 per cent of their needles, and yet no trees on the plots died. Top kill was common, but in most cases only one or a few years of terminal growth was killed back. Branch tips were killed but adventitious budding was so heavy that recovery was rapid. Radial growth started to improve the year following the first year of light defoliation.

The absence of tree mortality can perhaps be explained by comparison with a spruce budworm outbreak in northwestern Ontario. Mortality to balsam fir and spruce did not appear until after at least four years of continuous defoliation (2). Also, the infestation in Ontario started in 1937 and continued until 1955, a much longer period of time than the six years recorded in the Lillooet River Valley. The ability of Douglas fir to recover from severe damage, the relatively short duration of the outbreak, and the fact that no locality was subjected to more than two years of continuous severe defoliation are probably the main reasons for the absence of tree mortality.

\section{ACKNOWLEDGEMENTS}

The author wishes to acknowledge the help given by members of the Forest Insect Survey at Victoria and Vernon who assisted in the field and laboratory aspects of this study. The comments of Mr. R. R. Lejeune and Mr. A. F. Hedlin, of the Forest Biology Laboratory at Victoria, were helpful in preparing and revising the manuscript.

\section{Literature CTted}

1. ChapmaN, J. D. 1952. The climate of British Columbia. Fifth B.C. Nat. Resource Conf. 8-37.

2. ELLIOTT, K. R. 1960. A history of recent infestations of the spruce budworm in northwestern Ontario, and an estimate of resultant timber losses. For. Chron. 36: 61-82.

3. McGUGAN, B. M. 1954. Needle mining habits and larval instars of the spruce budworm. Can. Ent., 86(10): 439-454.

4. McGUGAN, B. M., and J. R. BLAIS. 1959. Spruce budworm parasite studies in northwestern Ontario. Can. Ent. 91: 758-783.

5. WELLINGTON, W. G., FETTES, J. J., TURNER, K. B. and R. M. BELYEA. 1950. Physical and biological indicators of the development of outbreaks of the spruce budworm, Choristoneura fumiferana (Clem.) (Lepidoptera: Torticidae). Can. Jour. Res. D. 28: 308-331.

6. WILKES, A., COPPEL, H. C. and W. G. MATHERS. 1948. Notes on the insect parasites of the spruce budworm, Choristoneura fumiferana (Clem.) in British Columbia. Can. Ent. 80: $138-155$. 